\title{
Pengeringan Dan Penyimpanan Serbuk Sari Mentimun (Cucumis Sativus L.) Serta Pemanfaatannya Dalam Produksi Benih Hibrida
}

\author{
Cucumis sativus pollen drying and storage and it's utilization for hybrid seed production \\ Rotua Melisa Sidabutar ${ }^{1}$, Endah Retno Palupi ${ }^{*}$, dan Karyadi Wanafiah ${ }^{2}$ \\ ${ }^{1}$ Departemen Agronomi dan Hortikultura, Fakultas Pertanian, Institut Pertanian Bogor \\ (Bogor Agricultural University), Jl. Meranti, Kampus IPB Darmaga, Bogor 16680, Indonesia \\ Telp.\&Faks. 62-251-8629353 e-mail agronipb@ indo.net.id \\ ${ }^{2}$ PT. East West Seed Indonesia, Desa Benteng Campaka Purwakarta PO Box 1 Campaka Purwakarta \\ Purwakarta, Jawa Barat, 41181 \\ *)Penulis untuk korespondensi : erpalupi@yahoo.co.id
}

Disetujui 24 Desember 2013/ Published online 13 Februari 2014

\begin{abstract}
The objectives of this research were to study the effect of decreasing water content during drying on germination of cucumber pollen KE014, change in germinability of cucumber pollen KE014 during storage, and it's potential for hybrid seed production. In the first and the second experiment, pollen was dried for 8 , 16, and 24 hours in $\mathrm{MgCl}_{2}$ and then was stored for 56 days in ultrafreezer. The germinability was observed during drying and storage. In the third experiment, the stored pollen was used for pollination to produce hybrid seed. The results showed, drying pollen for 8 hours decreased the water content considerably from $12.048 \%$ to $6.705 \%$, whereas germinability increased from $10.16 \%$ to $25.60 \%$. Prolong drying didn't decrease water content significantly. Drying for 8 hours maintained the germinability for 56 days in storage. Pollen drying increased it's potential for fruit set and seed content but did not the germinability and 1000 seed weight. Therefore, cucumber pollen KE014 needs to be dried at least 8 hours upon harvesting in order to be stored and used in hybrid seed production.
\end{abstract}

Keywords: cucumber, hybrid seed, pollen drying, storage, water content.

\section{ABSTRAK}

Penelitian ini bertujuan mempelajari pengaruh penurunan kadar air selama pengeringan dengan daya berkecambah serbuk sari mentimun KE014 dan kemampuannya dalam produksi benih hibrida. Percobaan pertama dan kedua, serbuk sari KE014 dikeringkan selama 8, 16, dan 24 jam dalam $\mathrm{MgCl}_{2}$, setelah itu disimpan selama 56 hari dalam ultrafreezer. Daya berkecambah diamati selama pengeringan dan penyimpanan. Pada percobaan tiga, serbuk sari KE014 di penyimpanan, digunakan dalam penyerbukan untuk produksi benih hibrida. Hasil menunjukkan, pengeringan serbuk sari selama delapan jam menurunkan kadar air secara nyata dari $12.05 \%$ menjadi $6.71 \%$, sedangkan daya berkecambah meningkat dari $10.16 \%$ menjadi $25.60 \%$. Pengeringan lebih lama tidak menurunkan kadar air secara signifikan. Pengeringan selama 8 jam mempertahankan daya berkecambah serbuk sari selama 56 hari penyimpanan. Pengeringan serbuk sari KE014 meningkatkan kemampuannya dalam pembentukan buah dan biji, tetapi tidak untuk daya berkecambah dan bobot 1000 butir benih. Oleh karena itu, serbuk sari KE014 perlu dikeringkan minimum selama 8 jam setelah panen untuk dapat disimpan dan digunakan dalam produksi benih hibrida.

\section{PENDAHULUAN}

Mentimun (Cucumis sativus L.) merupakan salah satu jenis sayuran dari keluarga labu-labuan (Cucurbitaceae) yang banyak dikonsumsi oleh berbagai lapisan masyarakat. Produksi mentimun pada tiga tahun terakhir di
Indonesia berfluktuasi dari 583,139 ton pada tahun 2009 menjadi 547,141 ton pada tahun 2010, menurun sebesar $6.17 \%$ (BPS, 2013). Pada tahun 2011 mengalami penurunan produksi, menjadi 521,535 ton, menurun sebesar $4.67 \%$ (BPS, 2013). Berdasarkan data statistik pertanian Indonesia, luas areal panen mentimun tahun 
2009, 2010, dan 2011 berturut-turut adalah 56,009; 56,921; dan 53,758 ha (Deptan, 2013). Salah satu upaya untuk mendukung peningkatan produksi dan produktivitas adalah melalui penggunaan benih hibrida. Benih hibrida adalah benih generasi $F_{1}$ yang dijual untuk produksi komersial.

Produksi benih hibrida di perusahaan benih swasta umumnya dikerjasamakan dengan petani penangkar dengan pengawasan yang ketat. Dalam rangka menjamin keamanan plasma nutfah dan meningkatkan efisiensi penggunaan lahan serta menjamin ketersediaan serbuk sari, maka pengelolaan serbuk sari mulai dikembangkan. Pengelolaan serbuk sari mencakup panen, penanganan, penyimpanan dan pengujian mutu serbuk sari.

Penanganan serbuk sari dimulai sesaat setelah panen sampai serbuk sari siap disimpan, umumnya mencakup ekstraksi dan pengeringan. Dalam penanganan serbuk sari mentimun, pengeringan dilakukan dua tahap. Pengeringan tahap pertama dilakukan setelah ekstraksi antera dari bunga jantan pada ruang ber-AC (suhu 22$25^{\circ} \mathrm{C}$, RH 60\%) selama 24 jam. Pengeringan tahap kedua dilakukan setelah ekstraksi serbuk sari dari antera dilakukan dalam boks yang berisi $\mathrm{MgCl}_{2}$ (suhu $26-27^{\circ} \mathrm{C}, \mathrm{RH} 35-45 \%$ ) selama 24 jam pada ruang ber-AC.

Hasil penelitian Fariroh et al. (2011) menunjukkan bahwa pengeringan serbuk sari baik tahap pertama maupun tahap kedua mengakibatkan penurunan daya berkecambah. Pengeringan antera dalam ruang ber-AC dengan suhu $22-25^{\circ} \mathrm{C}$ selama 24 jam menurunkan daya berkecambah serbuk sari mentimun yang dipanen pada saat antesis dari $12.02 \%$ menjadi $6.93 \%$, kemudian mengalami penurunan daya berkecambah lebih jauh lagi pada pengeringan tahap kedua menjadi $0.32 \%$. Penurunan daya berkecambah tersebut diduga disebabkan karena waktu pengeringan yang terlalu lama dalam dua kali proses pengeringan serbuk sari.

Serbuk sari buah naga, Hylocereus spp (Cactaceae) yang dikumpulkan pada pagi hari, memiliki kadar air yang relatif tinggi sekitar 18$22 \%$. Kemudian setelah mengalami dehidrasi selama 1 jam dalam silica gel, kadar air berkisar antara 5-10\%. Setelah mencapai kisaran kadar air tersebut, serbuk sari mampu disimpan untuk jangka waktu 3 dan 9 bulan, dengan suhu penyimpanan $+4,-18,-70$, dan $-196^{\circ} \mathrm{C}$ (Metz et al., 2000).

Pengeringan serbuk sari bertujuan untuk menurunkan kadar airnya sehingga daya simpannya lebih panjang (Connor dan Towill, 1993). Umumnya pengeringan mempengaruhi viabilitas serbuk sari. Oleh karena itu perlu ditentukan prosedur pengeringan yang sesuai dengan jenis serbuk sari tertentu (Metz et al., 2000).

Serbuk sari Cucurbita pepo (Cucurbitaceae) cepat kehilangan viabilitasnya ketika dikeringkan/dehidrasi. Viabilitas serbuk sari Cucurbita pepo menurun dengan cepat dan mencapai sekitar 1\% selama 24 jam (Nepi dan Pacini,1993). Wang et al. (2004); Khan dan Perveen (2009) menyatakan bahwa faktor utama yang berperan dalam mempertahankan viabilitas serbuk sari selama penyimpanan adalah kadar air serbuk sari dan suhu ruang simpan. Kedua parameter tersebut berdampak pada viabilitas serbuk sari pada periode penyimpanan singkat ataupun lama. Oleh karena itu perlu dilakukan penelitian untuk mengetahui lama pengeringan serbuk sari mentimun (Cucumis sativus L.) yang dapat menurunkan kadar air tetapi tetap mempertahankan viabilitas serbuk sari selama pengolahan dan penyimpanan.

Tujuan utama pengelolaan serbuk sari mulai dari panen, pengolahan, dan penyimpanan adalah agar serbuk sari tersebut dapat dimanfaatkan dalam produksi benih hibrida. Oleh karena itu, serbuk sari yang telah disimpan dalam penelitian ini digunakan untuk produksi benih hibrida mentimun.

\section{BAHAN DAN METODE}

Penelitian ini dilaksanakan pada bulan Maret sampai September 2012 di Lahan Percobaan Production Farm dan Laboratorium PT. East West Seed Indonesia, Jember, Jawa Timur. Bahan tanaman yang digunakan adalah tanaman induk jantan dalam produksi benih mentimun hibrida (KE014M), dari fase perkembangan bunga sehari sebelum antesis (A-1) dan tanaman induk betina (KE014F). Media perkecambahan serbuk sari menggunakan media PGM F (Fariroh et al., 2011) dengan komposisi 5 g sukrosa, $0.01 \mathrm{~g} \mathrm{H}_{3} \mathrm{BO}_{3}, 0.025 \mathrm{~g} \mathrm{CaCl}_{2}, 0.032 \mathrm{~g}$ $\mathrm{KH}_{2} \mathrm{PO}_{4}, 3$ g PEG 4000, dan $50 \mathrm{ml}$ aquadest. Bahan pengering serbuk sari menggunakan $\mathrm{MgCl}_{2}$. Peralatan yang dibutuhkan dalam proses pengecambahan serbuk sari adalah seperangkat alat pembuat larutan, deck glass, jarum ose, boks pengujian, pipet, hand counter, cryovial, tissue, deck glass, timbangan digital, termometer, hygrometer (alat ukur RH), aluminium foil, mikroskop cahaya Olympus CX41. Ruang 
simpan serbuk sari yang digunakan selama proses penyimpanan adalah ultra freezer $(-79 \pm 2)^{0} \mathrm{C}$. Peralatan yang digunakan dalam proses penyerbukan buatan adalah cotton bud, kertas, staples, benang penanda, alat penyungkup bunga, dan dry ice.

Percobaan 1. Perubahan kadar air dan daya berkecambah serbuk sari KE014 selama pengeringan

Rancangan yang digunakan adalah Rancangan Acak Lengkap (RAL) satu faktor yaitu lama pengeringan serbuk sari yang terdiri dari 4 taraf, yaitu $0,8,16$, dan 24 jam pengeringan (JP). Taraf 0 jam pengeringan merupakan taraf perlakuan dimana serbuk sari yang diekstrak dari antera yang telah dikeringkan dalam ruang-AC selama 24 jam tidak dikeringkan lagi dalam $\mathrm{MgCl}_{2}$. Serbuk sari yang sudah diekstrak dari antera untuk taraf 8,16 , dan 24 jam dikeringkan dalam boks berisi $\mathrm{MgCl}_{2}$ dengan volume $\mathrm{MgCl}_{2}$ sebanyak 2 liter dalam boks yang berukuran $34 \mathrm{~cm} \times 26 \mathrm{~cm} \times 7 \mathrm{~cm}$ selama 24 jam pada ruang ber-AC, dengan suhu boks pengeringan $26-27^{\circ} \mathrm{C}$ dan $\mathrm{RH} 35-45 \%$. Serbuk sari yang dikeringkan sebanyak 34.743 gram/boks. Pengamatan dilakukan terhadap kadar air dan daya berkecambah yang dilakukan setiap interval waktu $0,8,16$ dan 24 jam pengeringan dan diulang sebanyak 3 kali.

Data dianalisis dengan menggunakan uji F. Jika berbeda nyata dilanjutkan dengan menggunakan uji lanjut DMRT pada taraf $\alpha=$ 0.05 . Regresi antara lama pengeringan dengan kadar air dianalisis berdasarkan persamaan regresi kuadratik sederhana. Rumus regresi kuadratik sederhana, yaitu $\mathrm{Y}=\alpha+\mathrm{bX}+\mathrm{cX^{2 }}$.

Percobaan 2. Perubahan daya berkecambah serbuk sari KE014 selama penyimpanan

Serbuk sari yang telah dikeringkan dengan $\mathrm{MgCl}_{2}$ kemudian dimasukkan dalam cryovial dan disimpan dalam ultrafreezer. Penelitian menggunakan rancangan petak tersarang, petak utama adalah periode simpan terdiri atas enam taraf $(0,7,14,21,28,35,42,49$, dan 56 hari setelah penyimpanan), anak petak adalah lama pengeringan dalam $\mathrm{MgCl}_{2}$ terdiri dari empat taraf $(0,8,16$, dan 24 jam pengeringan).

Setiap perlakuan diulang sebanyak 6 kali.Total satuan percobaan sebanyak 216 satuan percobaan. Daya berkecambah diamati dalam enam bidang pandang setiap satu satuan percobaan/deck glass. Total deckglass yang diamati untuk setiap pengujian adalah 72 deckglass. Data dianalisis dengan menggunakan uji F. Jika berbeda nyata maka akan dilanjutkan menggunakan uji lanjut DMRT pada taraf $\alpha=$ 0.05 .

Percobaan 3. Pemanfaatan serbuk sari KE014 dalam produksi benih hibrida

Percobaan ini menggunakan rancangan petak tersarang, dengan tiga ulangan, petak utama adalah periode simpan terdiri atas enam taraf $(2$, $7,14,21,28$, dan 56 hari setelah penyimpanan), anak petak adalah lama pengeringan dalam $\mathrm{MgCl}_{2}$ terdiri dari empat taraf $(0,8,16$, dan 24 jam). Total satuan percobaan yaitu 72 satuan percobaan. Setiap ulangan terdiri dari 5 tanaman. Untuk setiap periode simpan, ditanam sebanyak 60 tanaman induk betina untuk proses penyerbukan. Pengamatan yang dilakukan yaitu terhadap pembentukan buah, hasil benih, dan mutu benih (daya berkecambah dan bobot 1000 butir). Data dianalisis dengan menggunakan uji F. Jika berbeda nyata dilanjutkan dengan menggunakan uji lanjut DMRT pada taraf $\alpha=0.05$.

\section{HASIL DAN PEMBAHASAN}

Percobaan 1. Perubahan kadar air dan daya berkecambah serbuk sari KE014 selama pengeringan

Pengeringan bertujuan untuk menurunkan kadar air serbuk sari agar lebih tahan simpan. Pengeringan serbuk sari pada 8 jam pertama menurunkan kadar air serbuk sari mentimun KE014 dari $12.05 \%$ menjadi $6.71 \%$, menurun hampir separuhnya (Tabel 1).

Tabel 1. Perubahan kadar air dan daya berkecambah serbuk sari KE014 selama pengeringan

\begin{tabular}{|c|c|c|}
\hline $\begin{array}{c}\text { Lama } \\
\text { pengeringan } \\
\text { (jam) }\end{array}$ & Kadar air (\%) & Viabilitas (\%) \\
\hline 0 & $12.05^{\mathrm{a}}$ & $10.16^{\mathrm{b}}$ \\
\hline 8 & $6.71^{\mathrm{b}}(-44.3)$ & $25.60^{\mathrm{a}}(151.9)$ \\
\hline 16 & $5.98^{\mathrm{bc}}(-10.8)$ & $10.65^{\mathrm{b}}(-58.4)$ \\
\hline 24 & $5.76^{\mathrm{c}} \quad(-3.7)$ & $22.01^{\mathrm{a}}(106.8)$ \\
\hline KK (\%) & 4.75 & $18.49^{(t)}$ \\
\hline \multicolumn{3}{|c|}{$\begin{array}{l}\text { Angka-angka yang diikuti oleh satu huruf atau lebih } \\
\text { huruf yang sama menunjukkan tidak adanya perbedaan } \\
\text { yang nyata pada tingkat kepercayaan } 95 \% \text {; Data telah } \\
\text { ditransformasi }(\sqrt{ } \times \text { x }) \text {. Angka dalam kurung menunjukkan } \\
\text { persentase penurunan/kenaikan kadar air dan daya } \\
\text { berkecambah serbuk sari }\end{array}$} \\
\hline
\end{tabular}


Hasil pengamatan penurunan kadar air sebesar $44.3 \%$ ini memberikan indikasi bahwa sebagian besar air bebas yang terdapat di permukaan dan yang terkandung dalam serbuk sari terabsorbsi oleh $\mathrm{MgCl}_{2}$. Pengeringan dalam $\mathrm{MgCl}_{2}$ menurunkan kadar air yang diharapkan dapat memperpanjang daya simpannya. Penurunan kadar air setelah pengeringan 8 jam terjadi dengan laju yang lebih rendah. Setelah 24 jam kadar air serbuk sari sebesar $5.76 \%$.

Pengeringan serbuk sari delapan jam pertama, meningkatkan daya berkecambah serbuk sari sebesar $151.9 \%$, meningkat dari $10.16 \%$ menjadi $25.60 \%$. Namun pengeringan delapan jam berikutnya, menunjukkan penurunan menjadi $10.65 \%$. Peningkatan daya berkecambah serbuk sari pada delapan jam pertama, memberikan indikasi bahwa serbuk sari masih dalam fase pemasakan, sebagaimana dilaporkan oleh Fariroh et al. (2011). Hal ini memberikan indikasi bahwa sebelum antesis proses perkembangan bunga masih berlangsung, termasuk perkembangan serbuk sari di dalam antera, dan diduga proses perkembangan berakhir pada saat antesis. Hasil pengamatan dalam penelitian ini menunjukkan bahwa proses perkembangan serbuk sari dari bunga yang dipanen sebelum antesis dapat terus berlangsung selama dalam proses pengeringan, sehingga terjadi peningkatan daya berkecambah.

Connor dan Towill (1993) melaporkan bahwa pengeringan serbuk sari menggunakan $\mathrm{MgCl}_{2}$ yang diujikan pada serbuk sari spruce (Gymnospermae), pinus, pecan (sejenis kemiri), cattail (tanaman rawa), dan jagung dengan kisaran RH 33\% menunjukkan terjadinya dehidrasi yang cepat pada serbuk sari. Kisaran kadar air yang diperoleh selama 8 jam pengeringan dalam $\mathrm{MgCl}_{2}$, serbuk sari tanaman spruce, pinus, pecan, cattail , dan jagung yaitu 5.0\%, 5.4\%, 3.2\%, 3.6\%, dan $5.9 \%$. Hubungan antara pengukuran kadar air dengan lama pengeringan dijelaskan melalui persamaan regresi kuadratik sederhana. Nilai koefisien determinasi $\left(\mathrm{R}^{2}\right)$ yang diperoleh dari hasil analisis regresi hubungan lama pengeringan serbuk sari dengan kadar air sebesar 0.952, artinya terdapat hubungan yang sangat erat antara keragaman dalam nilai-nilai kadar air dengan perlakuan lama pengeringan serbuk sari. Semakin lama pengeringan kisaran 0-24 jam menunjukkan pengaruh penurunan kadar air serbuk sari. Persamaan kuadratik yang diperoleh adalah : $\mathrm{Y}=$ $11.84-0.7252 X+0.02002 X^{2}$ (Gambar 1).

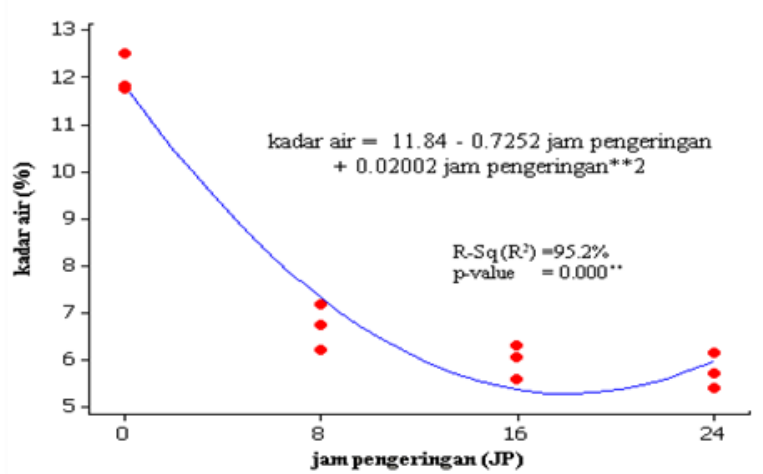

Gambar 1. Grafik hubungan kuadratik antara jam pengeringan dan kadar air serbuk sari mentimun KE014.

Percobaan 2. Perubahan daya berkecambah serbuk sari KE014 selama penyimpanan

Fariroh et al. (2011) menyatakan bahwa ruang simpan serbuk sari mentimun terbaik adalah ultra freezer. Interaksi antara lama pengeringan dan periode simpan berpengaruh terhadap daya berkecambah serbuk sari (Tabel 2).

Serbuk sari tanpa pengeringan memiliki daya berkecambah awal yang paling rendah sebesar $10.16 \%$. Berdasarkan pengamatan, serbuk sari tanpa pengeringan hanya dapat disimpan untuk penyimpanan jangka pendek. Daya berkecambah serbuk sari 0JP selama 56 hari penyimpanan. sebesar 3.68\%.

Pengeringan serbuk sari selama 8 jam cukup memadai untuk menurunkan kadar air serbuk sari untuk disimpan. Selama 56 hari penyimpanan, daya berkecambah serbuk sari tetap terjaga sebesar $24.56 \%$, dengan persentase penurunan sebesar $4.06 \%$. Data ini menunjukkan pengeringan serbuk sari selama 8 jam cukup untuk mempertahankan daya berkecambah selama 56 hari penyimpanan.

Daya berkecambah serbuk sari berfluktuasi selama penyimpanan dalam ultra freezer. Salah satu hal yang diduga menyebabkan daya berkecambah yang fluktuatif, yaitu kondisi pengecambahan serbuk sari yang berbeda/beragam. Menurut Hecker dan McClintock (1988), nilai daya berkecambah serbuk sari yang tidak konsisten, dapat disebabkan oleh kondisi dan teknik pengecambahan, serta lingkungan produksi serbuk sari.

Perlakuan 16 JP dan 24 JP menunjukkan, daya berkecambah di minggu awal saja tetap tinggi, namun mengalami penurunan di mingguminggu berikutnya. Daya berkecambah serbuk sari pada 24 JP meningkat selama di penyimpanan sampai 7 HSP menjadi $35.73 \%$, namun di periode 
penyimpanan selanjutnya daya berkecambah serbuk sari cenderung menurun hingga di akhir pengamatan 56 HSP menjadi $16.30 \%$. Hal ini diduga serbuk sari pada perlakuan 24 JP mencapai fase matang (daya berkecambah serbuk sari maksimum) saat periode penyimpanan 7 HSP.
Data menunjukkan, untuk penyimpanan jangka pendek lebih baik menggunakan waktu pengeringan serbuk sari selama 24 jam, sedangkan untuk penyimpanan jangka panjang lebih baik menggunakan waktu pengeringan selama 8 jam.

Tabel 2. Pengaruh interaksi periode simpan dan lama pengeringan terhadap daya berkecambah serbuk sari mentimun KE014

\begin{tabular}{|c|c|c|c|c|c|c|c|c|c|}
\hline \multirow{2}{*}{$\begin{array}{c}\text { Lama } \\
\text { pengeringan }\end{array}$} & \multicolumn{9}{|c|}{ Periode simpan } \\
\hline & 0 & 7 & 14 & 21 & 28 & 35 & 42 & 49 & 56 \\
\hline & & & & & $\%$ & & & & \\
\hline 0JP & $10.16^{\mathrm{klm}}$ & $12.79^{\mathrm{ijk} k}$ & $10.21^{\mathrm{jklm}}$ & $4.93^{\mathrm{op}}$ & $11.40^{\mathrm{ijkl}}$ & $6.89^{\mathrm{mno}}$ & $8.59^{1 \mathrm{mn}}$ & $5.93^{\text {nop }}$ & $3.68^{p}$ \\
\hline 8JP & $25.60^{\mathrm{b}}$ & $24.99^{\mathrm{b}}$ & $16.67^{\text {efghi }}$ & $14.07^{\text {hijk }}$ & $25.36^{\mathrm{b}}$ & $17.72^{\mathrm{c}-\mathrm{h}}$ & $24.27^{\mathrm{bc}}$ & $21.36^{\text {bcde }}$ & $24.56^{\mathrm{b}}$ \\
\hline $16 J P$ & $10.646^{\mathrm{jklm}}$ & $21.93^{\text {bcdefg }}$ & $24.83^{\mathrm{b}}$ & $10.78^{\mathrm{jklm}}$ & $30.73^{\mathrm{a}}$ & $20.67^{\text {bcdefg }}$ & $15.12^{\text {fghij }}$ & $17.56^{\text {defgh }}$ & $16.16^{\text {efghi }}$ \\
\hline $24 \mathrm{JP}$ & $20.65^{\text {bcdef }}$ & $35.73^{\mathrm{a}}$ & $12.54^{\mathrm{i}-1}$ & $18.13^{\text {efghi }}$ & $15.50^{\text {ghij }}$ & $23.95^{\text {bcd }}$ & $19.41^{\text {bcdefg }}$ & $16.11^{\text {efghi }}$ & $16.30^{\text {efghi }}$ \\
\hline
\end{tabular}

Percobaan 3. Pemanfaatan serbuk sari KE014 dalam produksi benih hibrida

Pengaruh faktor periode simpan dan lama pengeringan terhadap peubah pembentukan buah, hasil benih, daya berkecambah, dan bobot 1000 butir benih menunjukkan nilai yang berbeda. Interaksi antara periode simpan dan lama pengeringan berpengaruh terhadap bobot 1000 butir benih (Tabel 3).

Tabel 3. Sidik ragam pengaruh periode simpan, lama pengeringan, dan interaksinya pada produksi benih mentimun KE014

\begin{tabular}{ccccc}
\hline \multirow{2}{*}{ Peubah } & \multicolumn{4}{c}{ Perlakuan dan interaksinya } \\
\cline { 2 - 5 } & PS & LP & PSxLP & KK $(\%)$ \\
\hline Pembentukan buah & $* *$ & $* *$ & tn & 20.21 \\
Hasil benih & tn & $* *$ & tn & 28.67 \\
Daya berkecambah & $* *$ & $* *$ & tn & 2.27 \\
Bobot 1000 butir & $* *$ & tn & $*$ & 3.90 \\
\hline Keterangan: tn= tidak berpengaruh nyata, * = berpengaruh nyata \\
(5\% DMRT), **= berpengaruh sangat nyata (1\% \\
DMRT), KK= koefisien keragaman; PS (periode \\
simpan); LP (lama pengeringan)
\end{tabular}

Perlakuan tanpa pengeringan $0 \quad$ JP menunjukkan nilai rata-rata persentase pembentukan buah yang terendah dibandingkan perlakuan 8, 16, dan $24 \mathrm{JP}$ (Tabel 4).

Serbuk sari yang telah mengalami pengeringan $\left(\mathrm{MgCl}_{2}\right) \quad 8, \quad 16$, dan 24 jam menunjukkan kemampuan serbuk sari dalam pembentukan buah dan hasil benih. Berdasarkan data, serbuk sari tanpa pengeringan menunjukkan nilai rata-rata persentase pembentukan buah (5.23\%) dan hasil benih (35.69\%) (Tabel 4).

Hal ini diduga karena serbuk sari tanpa pengeringan memiliki struktur yang menggumpal (tidak remah), sehingga saat dilakukan penyerbukan, serbuk sari tidak menempel seutuhnya pada kepala putik. Selain itu kadar air (12.05\%) yang tinggi pada serbuk sari yang tidak dikeringkan akan membentuk kristal es selama penyimpanan yang akan merusak membran sel serbuk sari, sebagai akibatnya serbuk sari tidak mampu berkecambah ketika menempel di kepala putik. Rata-rata daya berkecambah benih yang dihasilkan, tidak berbeda antara pengeringan 8 jam (99.63\%), 16 jam (99.56\%), dan 24 jam (98.36\%). Sedangkan 0 jam memiliki rata-rata daya berkecambah yang lebih rendah, sebesar $95.58 \%$.

Interaksi antara periode simpan dan lama pengeringan serbuk sari berpengaruh terhadap bobot 1000 butir benih, diduga interaksi ini tidak hanya dipengaruhi oleh faktor perlakuan, tetapi salah satu faktor yang mempengaruhi adalah kondisi tanaman. Kondisi tanaman yang diserbuk dengan serbuk sari 28 HSP, terserang penyakit busuk daun dan busuk buah sehingga mempengaruhi proses pengisian biji. Wijoyo (2012) menyatakan bahwa penyakit busuk daun (Downey Mildew) ditandai dengan warna daun yang berubah menjadi coklat membusuk dan terdapat bercak-bercak kuning berjamur. Sedangkan penyakit busuk buah Phytophora ditandai dengan bercak kebasah-basahan yang 
berubah menjadi lunak dan berwarna coklat pada buah.

Rata-rata bobot 1000 butir benih periode 28 HSP terendah sebesar 25.58 g. Hasil benih dari penyerbukan dengan menggunakan serbuk sari yang telah disimpan sampai dengan 56 HSP memenuhi standar bobot 1000 butir benih mentimun KE014, kecuali hasil benih dari serbuk sari 28 HSP. Data pada Tabel $4\left({ }^{(3)}\right.$ dan $\left.^{(4)}\right)$ juga menunjukkan bahwa mutu benih hibrida yang dihasilkan dari penyerbukan menggunakan serbuk sari yang telah disimpan memenuhi standar pemasaran benih, walaupun ada kecendrungan semakin lama penyimpanan serbuk sari, maka semakin menurun mutu benih yang dihasilkan.

Tabel 4. Pengaruh periode simpan, lama pengeringan serbuk sari, dan interaksinya terhadap kemampuan serbuk sari dalam pembentukan buah, hasil benih, daya berkecambah, dan bobot 1000 butir benih

\begin{tabular}{|c|c|c|c|c|c|c|c|}
\hline \multirow{2}{*}{$\begin{array}{c}\text { Lama } \\
\text { pengeringan }\end{array}$} & \multicolumn{6}{|c|}{ Periode simpan } & \multirow{2}{*}{ Rata-rata } \\
\hline & 2 & 7 & 14 & 21 & 28 & 56 & \\
\hline & \multicolumn{7}{|c|}{ (1) pembentukan buah (\%) } \\
\hline 0 & $5.08^{\mathrm{a}}$ & $1.30^{\mathrm{c}}$ & $3.57^{\mathrm{b}}$ & $4.82^{\mathrm{b}}$ & $3.31^{\mathrm{b}}$ & $13.34^{\mathrm{a}}$ & $5.23^{\mathrm{b}}$ \\
\hline 8 & $11.45^{\mathrm{a}}$ & $35.72^{\mathrm{a}}$ & $25.27^{\mathrm{a}}$ & $19.78^{\mathrm{ab}}$ & $32.71^{\mathrm{a}}$ & $29.08^{\mathrm{a}}$ & $25.67^{\mathrm{a}}$ \\
\hline 16 & $3.18^{\mathrm{a}}$ & $16.18^{\mathrm{b}}$ & $22.81^{\mathrm{a}}$ & $23.82^{\mathrm{a}}$ & $32.00^{\mathrm{a}}$ & $24.05^{\mathrm{a}}$ & $20.34^{\mathrm{a}}$ \\
\hline 24 & $4.34^{\mathrm{a}}$ & $22.15^{\mathrm{b}}$ & $22.73^{\mathrm{a}}$ & $31.77^{\mathrm{a}}$ & $23.55^{\mathrm{a}}$ & $34.48^{\mathrm{a}}$ & $23.17^{\mathrm{a}}$ \\
\hline \multirow[t]{2}{*}{ Rata-rata } & $6.01^{\mathrm{b}}$ & $18.84^{\mathrm{a}}$ & $18.60^{\mathrm{a}}$ & $20.05^{\mathrm{a}}$ & $22.89^{\mathrm{a}}$ & $25.23^{\mathrm{a}}$ & \\
\hline & & & & & & \multicolumn{2}{|c|}{${ }^{(2)}$ hasil benih (\%) } \\
\hline 0 & $14.02^{\mathrm{a}}$ & $31.02^{\mathrm{b}}$ & $29.87^{b}$ & $59.59^{\mathrm{a}}$ & $49.80^{\mathrm{a}}$ & $60.91^{\mathrm{a}}$ & $35.69^{b}$ \\
\hline 8 & $87.13^{\mathrm{a}}$ & $80.00^{\mathrm{a}}$ & $90.66^{\mathrm{a}}$ & $91.81^{\mathrm{a}}$ & $88.84^{\mathrm{a}}$ & $83.84^{\mathrm{a}}$ & $87.04^{\mathrm{a}}$ \\
\hline 16 & $58.73^{\mathrm{a}}$ & $85.74^{\mathrm{a}}$ & $92.35^{\mathrm{a}}$ & $89.35^{\mathrm{a}}$ & $92.03^{\mathrm{a}}$ & $82.66^{\mathrm{a}}$ & $83.47^{\mathrm{a}}$ \\
\hline 24 & $29.83^{\mathrm{a}}$ & $85.57^{\mathrm{a}}$ & $91.92^{\mathrm{a}}$ & $89.40^{\mathrm{a}}$ & $88.43^{\mathrm{a}}$ & $82.19^{\mathrm{a}}$ & $77.89^{\mathrm{a}}$ \\
\hline \multirow[t]{2}{*}{ Rata-rata } & $47.43^{\mathrm{b}}$ & $62.83^{\mathrm{ab}}$ & $76.20^{\mathrm{a}}$ & $82.53^{\mathrm{a}}$ & $79.77^{\mathrm{a}}$ & $77.40^{\mathrm{a}}$ & \\
\hline & \multicolumn{7}{|c|}{ (3) daya berkecambah benih (\%) } \\
\hline 0 & $91.67^{\mathrm{a}}$ & $96.33^{\mathrm{b}}$ & $93.67^{\mathrm{b}}$ & $95.67^{\mathrm{b}}$ & $96.17^{\mathrm{b}}$ & $100.00^{\mathrm{a}}$ & $95.58^{\mathrm{b}}$ \\
\hline 8 & $98.17^{\mathrm{a}}$ & $100.00^{\mathrm{a}}$ & $100.00^{\mathrm{a}}$ & $100.00^{\mathrm{a}}$ & $99.83^{\mathrm{a}}$ & $99.83^{\mathrm{a}}$ & $99.63^{\mathrm{a}}$ \\
\hline 16 & $98.33^{\mathrm{a}}$ & $99.83^{\mathrm{a}}$ & $99.92^{\mathrm{a}}$ & $99.67^{\mathrm{a}}$ & $100.00^{\mathrm{a}}$ & $99.67^{\mathrm{a}}$ & $99.56^{\mathrm{a}}$ \\
\hline 24 & $93.33^{\mathrm{a}}$ & $99.83^{\mathrm{a}}$ & $100.00^{\mathrm{a}}$ & $100.00^{\mathrm{a}}$ & $100.00^{\mathrm{a}}$ & $97.00^{\mathrm{a}}$ & $98.36^{\mathrm{a}}$ \\
\hline \multirow[t]{2}{*}{ Rata-rata } & $95.37^{\mathrm{b}}$ & $99.00^{\mathrm{a}}$ & $98.39^{\mathrm{a}}$ & $98.83^{\mathrm{a}}$ & $99.00^{\mathrm{a}}$ & $99.12^{\mathrm{a}}$ & \\
\hline & & & & & & \multicolumn{2}{|c|}{ (4)bobot 1000 butir benih $(\mathrm{g})$} \\
\hline 0 & $29.75^{\mathrm{abc}}$ & $30.25^{\mathrm{ab}}$ & $30.99^{\mathrm{a}}$ & $28.97^{\mathrm{abc}}$ & $28.24^{\mathrm{bc}}$ & $29.57^{\mathrm{abc}}$ & 29.62 \\
\hline 8 & $30.66^{\mathrm{a}}$ & $30.66^{\mathrm{a}}$ & $30.99^{a}$ & $28.43^{\mathrm{bc}}$ & $24.82^{\mathrm{d}}$ & $29.38^{\mathrm{abc}}$ & 29.15 \\
\hline 16 & $30.81^{\mathrm{a}}$ & $30.02^{\mathrm{ab}}$ & $31.05^{\mathrm{a}}$ & $28.08^{\mathrm{bc}}$ & $23.86^{\mathrm{d}}$ & $30.12^{\mathrm{ab}}$ & 28.99 \\
\hline 24 & $29.96^{\mathrm{abc}}$ & $30.82^{\mathrm{a}}$ & $30.81^{\mathrm{a}}$ & $27.79^{c}$ & $25.43^{\mathrm{d}}$ & $30.81^{\mathrm{a}}$ & 29.27 \\
\hline Rata-rata & $30.29^{\mathrm{a}}$ & $30.44^{\mathrm{a}}$ & $30.96^{\mathrm{a}}$ & $28.31^{\mathrm{b}}$ & $25.58^{\mathrm{c}}$ & $29.97^{\mathrm{a}}$ & \\
\hline
\end{tabular}

Keterangan: ${ }^{(1)(2)(3)}$ Angka-angka yang diikuti satu atau lebih huruf yang sama pada kolom yang sama menunjukkan tidak ada perbedaan yang nyata $(95 \%) ;{ }^{(4)}$ Angka-angka yang diikuti satu atau lebih huruf yang sama pada baris dan kolom yang sama menunjukkan tidak ada perbedaan yang nyata $(95 \%)$ DMRT. Data ditransformasi $\left({ }^{*}+5\right){ }^{(1)} \mathrm{kk}=20.21 \%$; ditransformasi $\sqrt{3+5}{ }^{(2)} \mathrm{kk}=28.67 \% ;{ }^{(3)} \mathrm{kk}=2.27 \% ;{ }^{(4)} \mathrm{kk}=3.90 \%$

\section{KESIMPULAN}

1. Penurunan kadar air serbuk sari mentimun KE014 yang dikeringkan dalam boks berisi $\mathrm{MgCl}_{2}$ terjadi selama 8 jam pertama, pengeringan selanjutnya tidak menurunkan kadar air secara nyata.

2. Pengeringan serbuk sari mentimun KE014 selama 8 jam dengan $\mathrm{MgCl}_{2}$ dapat mempertahankan daya berkecambah serbuk sari selama kisaran waktu 56 hari penyimpanan dalam ultrafreezer $(-79 \pm 2)^{0} \mathrm{C}$.

Pengeringan serbuk sari mentimun KE014 selama 24 jam dengan $\mathrm{MgCl}_{2}$ dapat digunakan untuk penyimpanan jangka pendek selama kisaran waktu 7 hari penyimpanan dalam ultrafreezer $(-79 \pm 2)^{0} \mathrm{C}$.

3. Pengeringan serbuk sari mentimun KE014 dalam boks berisi $\mathrm{MgCl}_{2}$, meningkatkan kemampuannya untuk produksi benih hibrida, 
tetapi tidak mempengaruhi mutu benih yang dihasilkan.

\section{UCAPAN TERIMA KASIH}

Kami mengucapkan terima kasih kepada PT. East West Seed Indonesia yang telah mendukung sarana dan prasarana penelitian ini.

\section{DAFTAR PUSTAKA}

Badan Pusat Statistik. 2013. Produksi sayuran di Indonesia 1997-2010. http://www.bps.go.id/tab sub/view.php? tabel $=1 \&$ daftar $=1 \&$ id_subyek $=55 \&$ nota $\underline{b=20}$. [21 Januari 2013].

Connor, K.F., L.E. Towill. 1993.Pollen handling protocol and hydration/dehydration characteristics of pollen for application to long-term storage. Euphytica 68:7784.

Delaplane, K.S., D.F. Mayer. 2009. Cucumber.http://ag.udel.edu/enwc/facult y/dmcaron/Pollination/cucumber.html. [18 Januari 2012].

Departemen Pertanian. 2013. Basis data statistik pertanian komoditas ketimun (hortikultura) tahun 2000-2010. http://database.deptan. go.id/ bdsp/ hasilKom.asp. [21 Januari 2013].

Fariroh, I., E.R. Palupi, D.S. Wahyudin. 2011. Media perkecambahan dan kondisi ruang simpan serbuk sari mentimun (Cucumis sativus L.). Prosiding Seminar Nasional Perhimpunan Hortikultura Indonesia. Perhimpunan Hortikultura Indonesia dan Institut Pertanian Bogor. Lembang. 431-438.

Hanna, W.W., L.E. Towil. 1995. Long-term pollen storage. Plant Breeding Rev. 13:179-207.

Hecker, R.J., M. McClintock. 1988. Sugarbeet pollen germination in vitro. J. Sugar Beet Res. 25:42-54.

Khan, S.A., A. Perveen. 2009. Maintenance of pollen germination capacity of Glycine $\max ($ L.) Merr., (Papilionaceae). Pak. J. Bot. 41(5):2083-2086.
Towill, L.E.1981. Liquid nitrogen preservation of pollen from tuber-bearing Solanum species. Hort. Sci. 16:177-179.

Wang, Z.Y., Y. Ge, M. Scott, G. Spangenberg. 2004. Viability and longevity of pollen from trangenic and nontransgenic tall fescue (Festuca arundinacea) (Poaceae) plants. Am. J. Bot. 91(4):523-530.

Wijoyo, P.M. 2012. Budi Daya Mentimun yang Lebih Menguntungkan. Pustaka Agro Indonesia. Jakarta. 104 hal. 